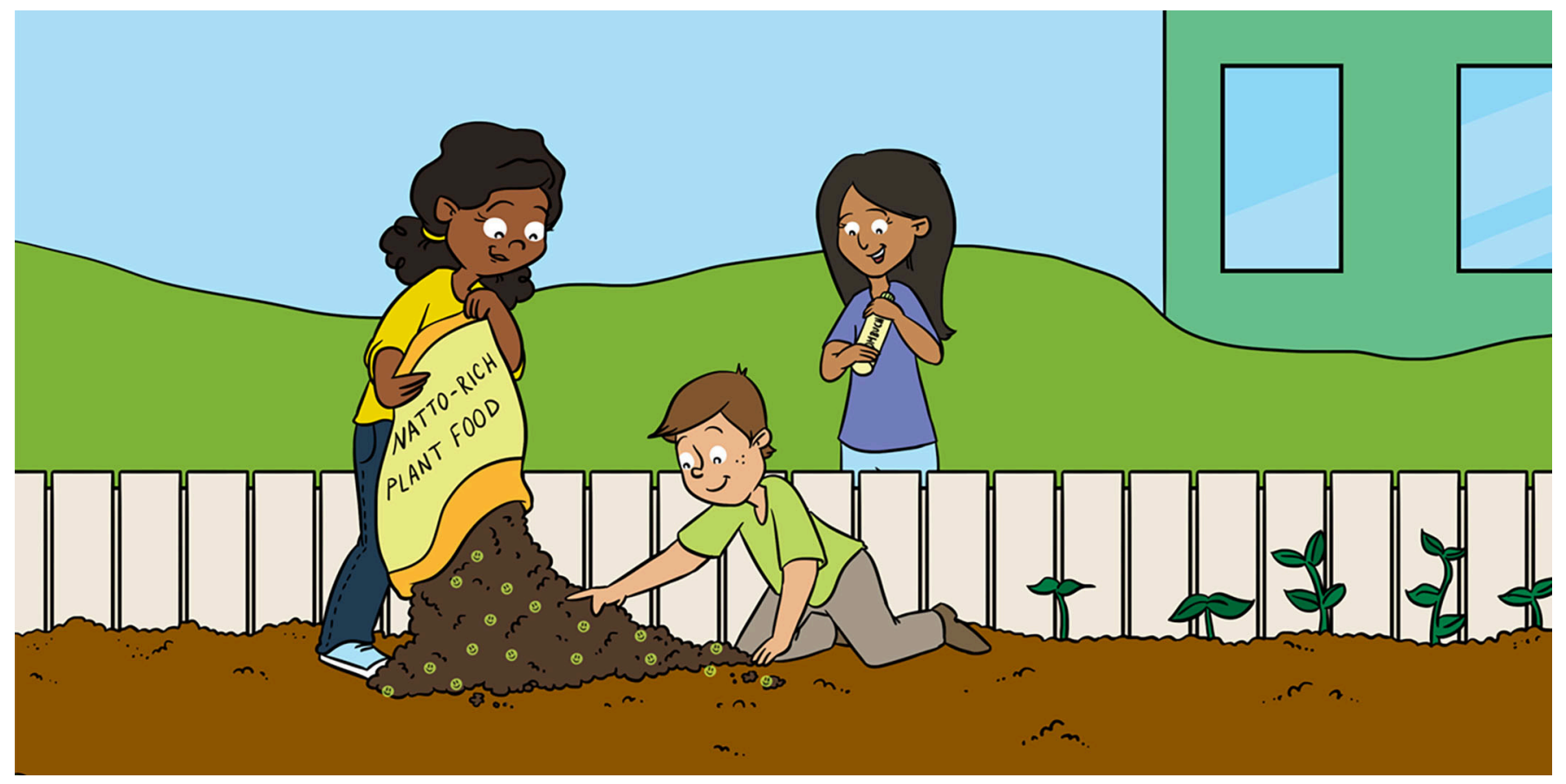

\title{
ONE TYPE OF SOIL BACTERIA PERFORMS TWO IMPORTANT JOBS TO HELP US PRODUCE HEALTHY FOOD
}

\section{Lauren S. McKee *}

Division of Glycoscience, Department of Chemistry, Royal Institute of Technology, Stockholm, Sweden

YOUNG REVIEWERS:

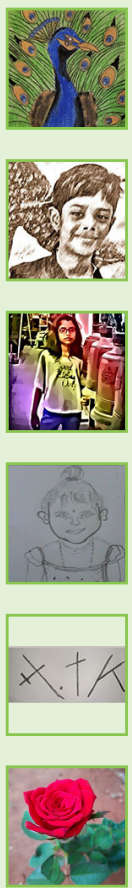

KAVIN

AGE: 9

ROHIT

AGE: 9

SWATI

AGE: 13

TANISHKAA

AGE: 8

TARUN

AGE: 13

THUVISHA

AGE: 13
Although they are small, bacteria perform some very important jobs that help us make healthy food. Food production starts with growing plants out in the field. Here, bacteria that live in the soil help plants to grow strong and tall, and they can even protect plants from some diseases. This way, the bacteria are helping the plants to stay healthy and they are helping the farmer to grow lots of food without using too much pesticide. After harvest, bacteria do even more work to make food that is tasty and good for your health, by making fermented superfoods like kimchi, kombucha, and natto. An example of a bacterium that can do both of these jobs is called Bacillus subtilis natto, and we have investigated what makes it such a useful and important species. We found that the natto bacterium produces important enzymes that can attack fungi that would cause plant disease. 


\section{BIOCONTROL}

The use of living organisms to control plant diseases, instead of using chemical pesticides. An example is using bacteria to control fungi that can damage plants.

\section{FERMENTATION}

\section{A process by which} microbes break down certain foods using enzymes, to turn the food into a different kind of substance. Common fermentation products include beer and yogurt.

\section{WHAT IS "BIOCONTROL"?}

The tiny bacteria that live in the soil can do a huge number of important jobs that help us to make nutritious and healthy food in a way that does not damage the environment. Some soil bacteria can protect crops like the soybean plant from diseases by fighting off the fungi that might cause an infection. We use the term biocontrol when we are using a living organism to protect our food. You can think of examples of biocontrol like using cats to keep rats away from food, or using ladybirds to eat aphids that can damage crops. Biocontrol helps us limit the growth of harmful organisms without using chemical pesticides. Pesticides can have lots of harmful effects on the environment, such as killing off the insects that pollinate plants and killing the microbes that keep plants healthy.

In our work, we are studying how bacteria can control the growth of fungi that would cause disease in crop plants. Normally, farmers use chemical pesticides to control these fungi, but many fungi are becoming resistant to the pesticides and are no longer affected by them, so they are getting harder to control. This means that farmers use more and more pesticide, causing more ecological damage, and making resistance spread even more! Using soil bacteria for biocontrol of fungi means that farmers can use less chemical pesticide on the fields where crop plants are growing. Using less pesticide is good for the soil, the air, the water, and for the insects that pollinate our plants, so these bacteria are protecting the whole environment, as well as helping us to grow food.

\section{THE NATTO BACTERIUM IS A SUPER-FERMENTER!}

After we harvest food from the field, sometimes it goes through processes in a factory to make it into something that is ready to eat, and soil bacteria are often used in these processes. In fact, many of the tools that bacteria use in food production are very similar to the tools other bacterial species use in the soil to control fungi. One bacterial species-Bacillus subtilis natto-can do both of these things!

The natto bacterium is part of the Bacillus group of species that are found in soils all around the world. This bacterium has been used for a very long time in Japan to make a food that is also called natto. This food is made when the natto bacterium turns soybeans into a sticky-and stinky-food substance, through a process called fermentation. Natto is very popular in Japan, where it is a common snack and breakfast food, and it is eaten with mustard and soy sauce. In fact, natto has been produced as food in Japan using Bacillus subtilis natto fermentation since the Taisho period, just after the First World War. The natto bacterium is also an icon of popular culture in Japan-one of the characters in the manga comic book and anime series called Moyasimon: Tales of Agriculture is a cute bacterium called 


\section{CHITIN}

A very strong polysaccharide found in the walls of fungal cells, which protects the cells from the environment and helps fungi to infect plant cells.

\section{POLYSACCHARIDE}

A long chain of sugar molecules connected by strong chemical bonds. For example, cellulose is made of long chains of the sugar glucose. Chitin is a polysaccharide made by fungi.

\section{ENZYME}

A type of protein that can catalyze a reaction, such as making or breaking the chemical bonds in carbohydrates. Enzymes that break down carbohydrates are very specific, acting only on chitin, cellulose, or some other polysaccharide.

\section{CHITINASE}

An enzyme that breaks chitin polysaccharide down into smaller pieces, called chitinoligosaccharides.
Natto. His job on the farm is to ferment soybeans to make the natto for the human characters to eat.

It is also becoming quite fashionable to eat natto in the rest of the world, because now we know that fermented foods are very good for human health [1]. Many fermented foods and drinks are now available in shops, including kombucha tea, kimchi pickles, tempeh, and yogurt, and all of these foods can help our digestion. Natto is high in fiber and contains a lot of vitamin $\mathrm{K}$, which we need to grow strong and healthy bones. By fermenting soybeans into natto, our natto bacteria are making a tasty snack that is great for your tummy and your whole body!

\section{HOW DOES NATTO CONTROL THE FUNGI THAT WOULD CAUSE PLANT DISEASES?}

Thanks to a recent project I was involved in, we now also know that our natto bacteria are probably making a big contribution to preventing fungal disease in some plants. The natto bacterium shows many of the important behaviors that we see in other plant-protecting bacteria. In particular, the natto bacterium can very effectively attack the cell wall that protects fungal cells [2]. Fungi, like the ones that can cause disease in soybean plants, have long, thin cells that grow quickly by extending one edge of the cell forwards in one direction, forming thin strands called filaments. These cells have a strong outer layer-called the fungal cell wall-that is partly made up of a material called chitin (Figure 1). Chitin is a polysaccharide, which is a very long molecule made up of lots of smaller sugar molecules joined together, and it is rigid and very strong. It acts like a suit of armor, protecting the fungal cell from the environment and from attack by other microbes. It also makes the fungal cell strong enough to break into plant tissue, which is how plant infection often begins.

Enzymes that can break down chitin into small pieces are therefore a very powerful weapon against fungi, because they damage the suit of armor, and let the fungal cell be exposed and killed. Plant-protecting bacteria in the soil produce enzymes called chitinases that can protect plants from infection with fungi. In fact, the chitinases that soil bacteria produce are one of the most important aspects of biocontrol [3]. Bacterial chitinases are also really important for the health and fertility of the whole soil ecosystem, because they break down dead fungal cells into small molecules that the bacteria can feed on. This is vital for the recycling of carbon and other elements [4], which is, after all, what drives life on Earth!

In our recent experiments, we showed that the soil bacterium Bacillus subtilis natto can produce enzymes that break down the chitin in fungal cell walls (Figure 2). In our lab tests, these enzymes could convert chitin polysaccharides into very small molecules called 
Figure 1

The fungal cell wall is the strong layer on the outside of a fungal cell that protects the cells from being killed. If the cell wall is broken, the fungus will die, and it will not be able to infect plants. The fungal cell wall is made of a strong polysaccharide (a long carbohydrate chain) called chitin, as well as protein and another polysaccharide called glucan. Bacteria in the soil produce enzymes that can attack chitin and break it down into smaller chunks called oligosaccharides (shorter carbohydrate chains).

\section{OLIGOSACCHARIDE}

A short chain of sugar molecules connected by strong chemical bonds.

Oligosaccharides are formed when an enzyme breaks down a polysaccharide into smaller pieces.

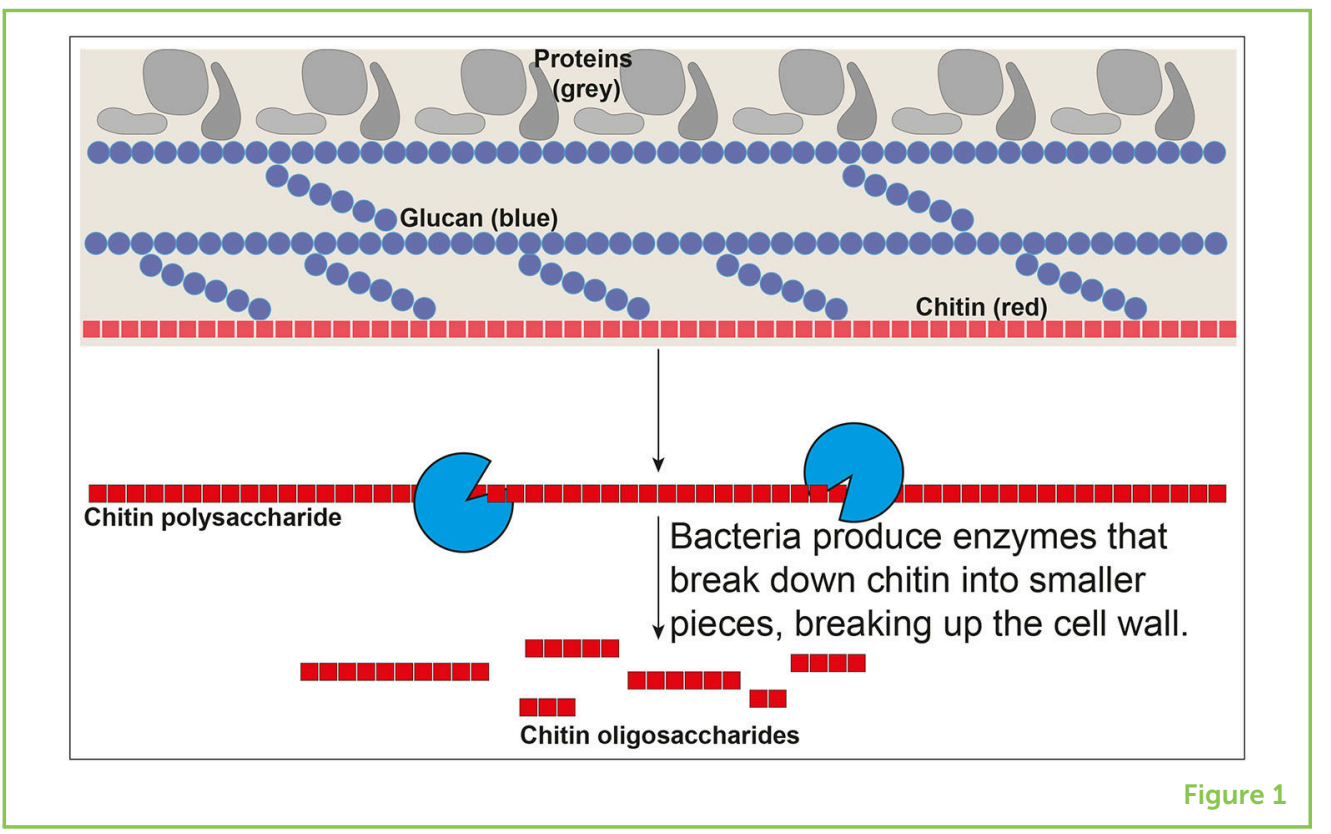

oligosaccharides, and they could also break up big clumps of fungal cell walls when these clumps were incubated with the enzymes.

However, we were surprised to see that the natto bacterium does not like to feed on chitin itself, and it will not produce chitinase enzymes if chitin is the only material it can find. Instead, the natto bacterium needs to find a complete fungal cell wall before it will produce chitinase enzymes.

\section{WHAT COMES NEXT IN OUR RESEARCH?}

Our results tell us that the natto bacterium can somehow sense when there is fungus in the local environment, and start producing powerful chitinase enzymes to break down the strongest parts of the fungal cell wall. Our results also tell us that we might be able to increase biocontrol behavior in Bacillus subtilis natto by mixing cell walls from dead fungus into the soil. Other researchers have shown that, for other bacteria, adding only chitin to the soil can cause an increase in chitinase production [5]. But for our natto bacterium, the story is more complicated.

In our tests, Bacillus subtilis natto also produced enzymes that break down protein, which is another important component in the fungal cell wall (Figure 1). I was excited by this, because these are the same enzymes that are used in the production of natto as food! The protein-degrading enzymes have been known for a long time, but now we have seen a whole new use for them.

We are now doing some extra experiments to test whether our methods for increasing chitinase production can increase the 
Figure 2

We grew cultures of Bacillus subtilis natto and treated them by adding either chitin, whole dead fungal cells, or fungal cell walls from dead fungus cells. Then we measured how much chitinase activity was produced by the bacterium in each treatment condition. You can clearly see that treating with chitin did not cause more chitinase activity to be produced, but treatment with fungal cells or fungal cell wall had a big impact.

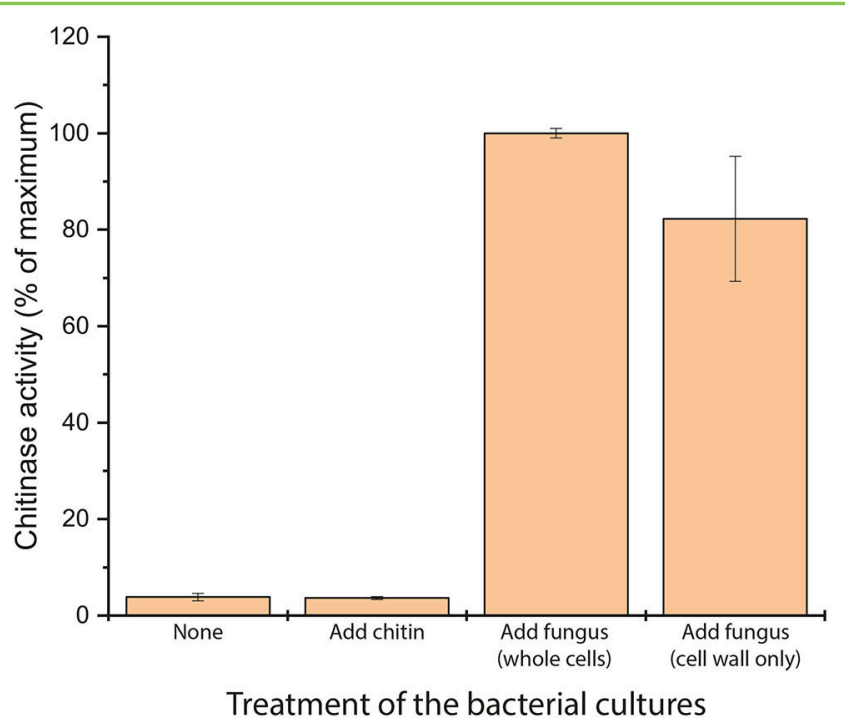

Figure 2

biocontrol ability of Bacillus subtilis natto and make it more effective at killing off the fungi that might harm plants. So far it looks quite promising, and we can see that several of the fungi we have tested are strongly affected by our natto bacterium. This means that Natto character from Moyasimon anime is actually performing two fantastic jobs on the farm and helping us in two different ways to have a good supply of healthy food!

\section{ORIGINAL SOURCE ARTICLE}

Schönbichler, A., Díaz-Moreno, S. M., Srivastava, V., and McKee, L. S. 2020. Exploring the potential for fungal antagonism and cell wall attack by Bacillus subtilis natto. Front. Microbiol. 11:521. doi: 10.3389/fmicb.2020.00521

\section{REFERENCES}

1. Dimidi, E., Cox, S. R., Rossi, M., and Whelan, K. 2019. Fermented foods: definitions and characteristics, impact on the gut microbiota and effects on gastrointestinal health and disease. Nutrients 11:1806. doi: 10.3390/nu11081806

2. Schönbichler, A., Díaz-Moreno, S. M., Srivastava, V., and McKee, L. S. 2020. Exploring the potential for fungal antagonism and cell wall attack by Bacillus subtilis natto. Front. Microbiol. 11:521. doi: 10.3389/fmicb.2020.00521

3. Beier, S., and Bertilsson, S. 2013. Bacterial chitin degradation-mechanisms and ecophysiological strategies. Front. Microbiol. 4:149. doi: 10.3389/fmicb.2013. 00149

4. McKee, L. S., and Inman, A. R. 2019. "Secreted microbial enzymes for organic compound degradation," in Microbes and Enzymes in Soil Health and Bioremediation, eds A. Kumar and S. Sharma (Singapore: Springer Singapore) (2019). p. 225-54. 
5. Cretoiu, M. S., Korthals, G. W., Visser, J. H. M., and van Elsas, J. D. 2013. Chitin amendment increases soil suppressiveness toward plant pathogens and modulates the actinobacterial and oxalobacteraceal communities in an experimental agricultural field. Appl. Environ. Microbiol. 79:5291.

doi: 10.1128/AEM.01361-13

SUBMITTED: 21 April 2020; ACCEPTED: 01 September 2020; PUBLISHED ONLINE: 15 October 2020.

EDITED BY: Phillip R. Myer, The University of Tennessee, Knoxville, United States

CITATION: McKee LS (2020) One Type of Soil Bacteria Performs Two Important Jobs to Help Us Produce Healthy Food. Front. Young Minds 8:554161. doi: 10. 3389/frym.2020.554161

CONFLICT OF INTEREST: The author declares that the research was conducted in the absence of any commercial or financial relationships that could be construed as a potential conflict of interest.

COPYRIGHT @ 2020 McKee. This is an open-access article distributed under the terms of the Creative Commons Attribution License (CC BY). The use, distribution or reproduction in other forums is permitted, provided the original author(s) and the copyright owner(s) are credited and that the original publication in this journal is cited, in accordance with accepted academic practice. No use, distribution or reproduction is permitted which does not comply with these terms.

\section{YOUNG REVIEWERS}

\section{KAVIN, AGE: 9}

There are important and interesting things in science.

\section{ROHIT, AGE: 9}

My hobby is drawing and doing science projects. I want to do animated cartoons. My favorite sport is Cricket. I know the capitals and flags of all the countries. I also know some of the major inventions and their inventor's names.

\section{SWATI, AGE: 13}

The article was very informative. It was very interesting to learn about the natto bacterium. The words in the text were easy to understand. My time was spent useful during this quarantine. 

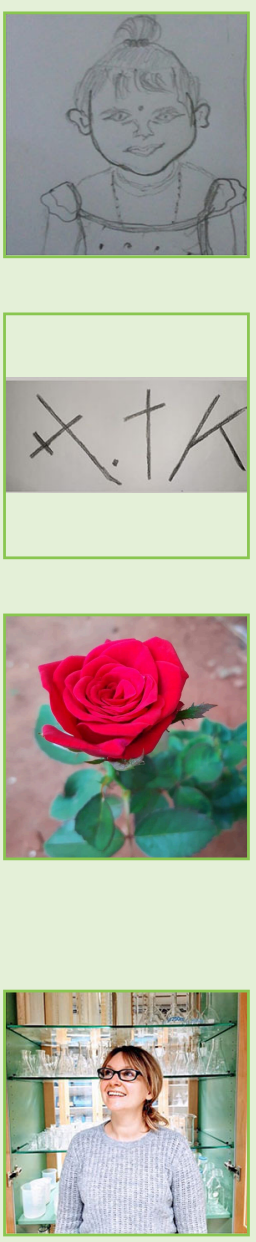

TANISHKAA, AGE: 8

I have been interested in learning science since my childhood. I would like to explore every part of science. My favorite part in science is learning about the human body. I like science very much because it is very very interesting. I want science to be with me as a part of my whole life.

\section{TARUN, AGE: 13}

I am a state player in badminton. I master all the techniques in badminton. I also love to play chess. I always win when I play with my friend.

\section{THUVISHA, AGE: 13}

I like Science because it is something new and makes you discover a lot of things that are related to your daily life. It is always interesting. Without science there is nothing in the world.

\section{AUTHOR}

\section{LAUREN S. MCKEE}

Lauren grew up in the North East of England and is currently living and working in Stockholm, Sweden. She studies bacterial biochemistry and the ways that different microbial species can interact with each other and their environment. She works in the lab and teaches students about microorganisms and how they can be used in industry. She is most interested in the enzymes that bacteria produce in the soil-these are very important in natural ecosystems and are also very valuable tools for the biotechnology industry. ${ }^{*}$ mckee@akth.se 